\title{
Purification and Properties of Xylan Degrading Enzymes Produced by Penicillium expansum O-385-10 Concerning Spoilage of Apple Fruit
}

\author{
Nobuko OHno*1, Harumi FukUda ${ }^{* 1}$, Soichiro Kimura ${ }^{* 2}$, \\ Hyun-Woong $\mathrm{KIm}^{* 2}$, Haruo TAKAHASHI ${ }^{* 3}$, Seigo AmaCHI ${ }^{* 2}$, \\ Hirofumi Shinoyama ${ }^{* 2}$ and Takaaki FujII ${ }^{* 2,}$ \\ (*1 Department of Health and Nutrition, School of Home Economics, Wayo Women's University, \\ 2-3-1 Konodai, Ichikawa-shi, Chiba 272-8533) \\ (*2 Department of Life and Bioresources Science, Graduate School of Science and \\ Technology, Chiba University, 648 Matsudo, Matsudo-shi, \\ Chiba $271-8510 ;{ }^{\dagger}$ Corresponding author) \\ (*3 Public Health Laboratory of Chiba Prefecture, 662-2 Nitona, Chuo-ku, \\ Chiba-city, Chiba 260-8715) \\ (Received June 21, 2004) \\ (Accepted October 24, 2004)
}

\begin{abstract}
Extracellular xylan-degrading enzymes (xylanase I, xylanase II and $\beta$-xylosidase) were purified as electrophoretically and isoelectrophoretically homogeneous proteins from the culture broth of Penicillium expansum O-385-10 concerning the spoilage of apple fruit. The molecular weights of xylanase I, xylanase II and $\beta$-xylosidase were $21.0,40.0$ and $91.0 \mathrm{kDa}$, respectively. The $\mathrm{p} I \mathrm{~s}$ of xylanase I, xylanase II and $\beta$-xylosidase were $9.20,4.30$ and 4.20 , respectively. Xylanase I produced xylose and several xylooligosaccharides from xylan. On the other hand, xylanase II mainly produced xylose and xylobiose from an early stage of the reaction, and oligosaccharides over xylotriose were almost absent. In the presence of $\mathrm{K}^{+}$ion, the activity of xylanase I increased almost two-fold, while the activity of xylanase II decreased to about $80 \%$. When xylanase I and II were simultaneously incubated with apple fruit, reducing sugar was hardly liberated from the fruit tissue, but the tissue was significantly affected by adding $\beta$-xylosidase to this incubation mixture, and a large amount of the sugar was liberated.
\end{abstract}

Key words: Xylanase, $\beta$-Xylosidase, Penicillium expansum, Apple fruit

\section{Introduction}

Penicillium expansum was found to be responsible for the post harvest spoilage of apples $^{1)}$. However, there is very little information on the relationship between the components of apple fruit and physiology of the fungus $^{2-7)}$. $\quad P$. expansum 0-385-10 extracellularly produced the xylan degrading enzyme and pectin degrading enzyme in a xylan medium and pectin medium, respectively. It was clarified by electron microscopy that the xylan degrading enzyme played a role in the decomposition of cell walls and the pectin degrading enzyme in the dissociation of the combination between cells ${ }^{2)}$. From these facts, it has been estimated that the xylan and pectin degrading enzymes play an important role in spoilage process of apple fruit by $P$. expansum. Only one of the pectin degrading enzymes (polygalacturonase) produced by the fungus has been purified until now, and the characteristics have been clarified ${ }^{8)}$. However, no reports on the purification and characterization of xylan degrading enzyme have appeared.

This paper deals with the purification and characterization of the xylan degrading enzyme produced by $P$. expansum growing in a medium containing washed wheat bran $^{9)}$ as a xylan source. Two xylanases and $\beta$-xylosidase 
were purified. Their properties were examined, and the action of these purified enzymes on apple fruit was also examined.

\section{Materials and Methods}

\section{Microorganism and culture conditions}

Penicillium expansum 0-385-10 was obtained from the National Institute of Health Sciences (Tokyo, Japan). Stock cultures were maintained on potato dextrose agar (PDA, Difco) slants ${ }^{2}$. The basal medium for enzyme production contained the following compounds (per liter): $\mathrm{KH}_{2} \mathrm{PO}_{4}, 2 \mathrm{~g} ; \mathrm{MgSO}_{4} \cdot 7 \mathrm{H}_{2} \mathrm{O}, 1 \mathrm{~g}$; $\left(\mathrm{NH}_{4}\right)_{2}$ $\mathrm{SO}_{4}, 5 \mathrm{~g}$; mineral solution, $2 \mathrm{ml}$; washed wheat bran $^{9)}$ as a xylan source, $20 \mathrm{~g}$. The mineral solution had the following composition (per liter): $\mathrm{FeSO}_{4} \cdot 7 \mathrm{H}_{2} \mathrm{O}, 0.05 \mathrm{~g}$; $\mathrm{CaCl}_{2} \cdot 2 \mathrm{H}_{2} \mathrm{O}, 0.10 \mathrm{~g}$; $\mathrm{MnSO}_{4} \cdot 4 \mathrm{H}_{2} \mathrm{O}, 0.02 \mathrm{~g} ; \mathrm{ZnSO}_{4} \cdot 7 \mathrm{H}_{2} \mathrm{O}, 0.02 \mathrm{~g}$. The pH was adjusted to 5.0 with $1 \mathrm{~N} \mathrm{NaOH}$, and the medium was sterilized by autoclaving at $121^{\circ} \mathrm{C}$ for $20 \mathrm{~min}$. One loop of the stock culture was inoculated on a PDA slant and then incubated at $30^{\circ} \mathrm{C}$ for a week. After the cultivation, $10 \mathrm{ml}$ of sterilized distilled water was added to the slant and shaken vigorously by a vortex mixer. This suspension $(0.2 \mathrm{~m} l)$ was inoculated to a $100-\mathrm{m} l$ Erlenmeyer flask containing $30 \mathrm{~m} l$ of the basal medium and incubated at $30^{\circ} \mathrm{C}$ on a rotary shaker $(160 \mathrm{rpm})$ for a week. After the incubation, cells were removed by centrifugation. The resulting supernatant was concentrated to one-eighth volume by a flash evaporator. To the concentrated solution, solid ammonium sulfate was added to give $70 \%$ saturation. The precipitate was collected by centrifugation and stored below $4^{\circ} \mathrm{C}$ until use.

\section{Enzyme assay}

Xylanase activity was determined by measuring the amount of the reducing sugar liberated from xylan (Sigma, from oat spelts). The reaction mixture contained $1.0 \mathrm{~m} l$ of the purified enzyme or crude enzyme preparation and $3.0 \mathrm{ml}$ of $0.5 \%$ xylan in $100 \mathrm{mM}$ sodium acetate buffer ( $\mathrm{pH}$ 5.0). After $20 \mathrm{~min}$ incubation at $30^{\circ} \mathrm{C}$, the reducing sugar in the reaction mixture was measured by the Somogyi-Nelson $\operatorname{method}^{10)}$. One unit(U) of xylanase was defined as the amount of enzyme that liberated $1 \mu \mathrm{mol}$ of xylose per min.

$\beta$-Xylosidase activity was measured by a spectrophotometric method with $p$-nitrophenyl
$\beta$-D-xylopyranoside (Sigma) as a substrate. The reation mixture contained $200 \mu \mathrm{l}$ of the substrate solution $(2 \mathrm{mM} \quad p$-nitrophenyl $\beta$-Dxylopyranoside in $50 \mathrm{mM}$ sodium phosphate buffer, pH 6.0), and $200 \mu l$ of diluted enzyme solution. After $10 \mathrm{~min}$ incubation at $30^{\circ} \mathrm{C}$, the reaction was stopped by the addition of $1.6 \mathrm{~m} l$ of $1 \mathrm{M} \mathrm{Na}_{2} \mathrm{CO}_{3}$. The absorbance at $405 \mathrm{~nm}$ due to the release of $p$-nitrophenol in the mixture was measured. One unit(U) of $\beta$-xylosidase was defined as the amount of enzyme that liberated $1 \mu \mathrm{mol}$ of $p$-nitrophenol per min in the reaction mixture under these assay conditions.

\section{Purification of xylan degrading enzymes}

The $70 \%$ saturated ammonium sulfate precipitate as described above was dissolved in a small amount of $10 \mathrm{mM}$ potassium phosphate buffer ( $\mathrm{pH}$ 7.45). The solution was dialyzed against the same buffer at $4^{\circ} \mathrm{C}$ overnight. All of the following procedures were carried out at $4^{\circ} \mathrm{C}$ unless otherwise indicated. The dialysate was centrifuged to remove insoluble substances and then applied on a DEAE-cellulose DE-52 (Whatman) column $(\phi 1.5 \times 40 \mathrm{~cm})$ equilibrated with $10 \mathrm{mM}$ phosphate buffer ( $\mathrm{pH} 7.45)$. The column was washed with the phosphate buffer and eluted with a linear gradient of sodium chloride (0 to $500 \mathrm{mM}$ ) dissolved in the same buffer. The xylanase activity was divided into the fraction (xylanase I) washed out and fraction (xylanase II) eluted from the column with the gradient buffer. The washout fractions were pooled and lyophilized. The lyophilized preparation was dissolved in a small amount of $10 \mathrm{mM}$ sodium acetate buffer ( $\mathrm{pH} 5.0$ ), and applied on a CM-cellulose 52 (Whatman) column $(\phi 1.5 \times 40 \mathrm{~cm})$ equilibrated with the same buffer. The column was washed with $400 \mathrm{ml}$ of the above buffer and eluted with a $1,000 \mathrm{~m} l$ linear gradient of sodium chloride (0 to 500 $\mathrm{mM})$ in the acetate buffer at a flow rate of 10 $\mathrm{ml} / \mathrm{hr}$. The active fractions were pooled and lyophilized. The lyophilized preparation was dissolved in a small amount of $10 \mathrm{mM}$ acetate buffer ( $\mathrm{pH}$ 5.0), and applied on a Sephadex G-100 (Pharmacia) column $(\phi 1.6 \times 70 \mathrm{~cm})$ previously equilibrated with the above buffer. The column was eluted with the same buffer at a flow rate of $7 \mathrm{ml} / \mathrm{hr}$. The active fractions were collected and concentrated by a Centriprep 10 concentrator (Amicon). The resultant prepara- 
tion was stored as the purified xylanase I at $-20^{\circ} \mathrm{C}$ for later analysis. In addition, the active fractions (xylanase II) eluted from the first DEAE-cellulose DE-52 column were pooled and lyophilized. The lyophilized preparation was dissolved in a small amount of $10 \mathrm{mM}$ acetate buffer ( $\mathrm{pH}$ 5.0). To the dissolved solution, ammonium sulfate was added to give $30 \%$ saturation. The ammonium sulfate solution was applied to a Butyl-Toyopearl 650M (Tosoh) column $(\phi 1.5 \times 40 \mathrm{~cm})$ equilibrated with the acetate buffer containing $30 \%$ saturation of ammonium sulfate. The column was eluted with a linear decreasing gradient of ammonium sulfate (30 to $0 \%$ ) in the acetate buffer at a flow rate of $10 \mathrm{ml} / \mathrm{hr}$. The active fractions were combined and lyophilized. The lyophilized preparation was dissolved in a small amount of $10 \mathrm{mM}$ acetate buffer ( $\mathrm{pH} 5.0$ ), and applied to a Sephadex G-150 (Pharmarcia) column $(\phi 1.6 \times 70 \mathrm{~cm})$ equilibrated with the acetate buffer. The column was eluted with the same buffer at a flow rate of $7 \mathrm{ml} / \mathrm{hr}$. The active fractions were combined and stored as a purified xylanase II at $-20^{\circ} \mathrm{C}$.

The above $70 \%$ saturated ammonium sulfate precipitate of the culture broth was dissolved in a minimal amount of $10 \mathrm{mM}$ potassium phosphate buffer ( $\mathrm{pH}$ 7.4). The resultant solution was dialyzed against the same buffer at $4^{\circ} \mathrm{C}$ overnight. The dialysate was centrifuged again to remove insoluble substances and then applied to a DEAE-cellulose DE-52 (Whatman) column $(\phi 1.5 \times 40 \mathrm{~cm})$ equilibrated with $10 \mathrm{mM}$ phosphate buffer ( $\mathrm{pH}$ 7.4) and washed with the same buffer. The column was eluted with a linear ( 0 to $500 \mathrm{mM}$ ) $\mathrm{NaCl}$ gradient in the buffer. The active fractions ( $\beta$-xylosidase) were combined and lyophilized. The lyophilized preparation was dissolved in a small amount of $10 \mathrm{mM}$ sodium acetate buffer ( $\mathrm{pH} 5.0$ ). To the dissolved solution, ammonium sulfate was added to give $30 \%$ saturation. The resulting solution was applied to a Butyl-Toyopearl $650 \mathrm{M}$ (Tosoh) column $(\phi 1.5 \times 40 \mathrm{~cm})$ equilibrated with the acetate buffer containing $30 \%$ saturation of ammonium sulfate. The column was eluted with a linear decreasing gradient of ammonium sulfate (30 to $0 \%$ ) dissolved in the acetate buffer at a flow rate of $10 \mathrm{ml} / \mathrm{hr}$. The active fractions were combined and lyophilized.
The lyophilized preparation was dissolved in a small amount of $10 \mathrm{mM}$ acetate buffer ( $\mathrm{pH} 5.0$ ), and applied to a Sephadex G-150 (Pharmarcia) column $(\phi 1.6 \times 70 \mathrm{~cm})$ equilibrated with the above buffer. The column was eluted with the same buffer at a flow rate of $7 \mathrm{ml} / \mathrm{hr}$. The active fractions were combined and stored as a purified $\beta$-xylosidase at $-20^{\circ} \mathrm{C}$.

\section{Protein assay}

Protein was measured by the method of Lowry et al. ${ }^{11)}$ with bovine serum albumin as a standard protein. Protein eluted from a column was monitored by measuring the absorbance at $280 \mathrm{~nm}$.

\section{Electrophoresis}

The native protein sample was directly run on a $5 \%$ polyacrylamide gel in $50 \mathrm{mM}$ Trisglycine buffer $(\mathrm{pH} \mathrm{8.3})^{12)}$. Electrophoresis of the denatured protein samples was done in $25 \mathrm{mM}$ Tris-glycine buffer ( $\mathrm{pH} 8.3$ ) containing $0.1 \%$ SDS on a $13.5 \%$ gel by the method of Laemmli $^{13,14)}$.

In both cases, protein was stained with $0.25 \%$ Coomassie brilliant blue R-250 in 50\% methanol-10\% acetic acid solution.

\section{Molecular weight estimation}

The molecular weight of the native enzyme was estimated by HPLC on a TSK G-3000 SW (Tosoh) column equilibrated with $50 \mathrm{mM}$ Tris$\mathrm{HCl}$ buffer ( $\mathrm{pH}$ 7.5) containing $0.1 \mathrm{M} \mathrm{NaCl}$. The column was eluted with the same buffer. In addition, the molecular weight of the denatured enzyme was estimated by SDS polyacrylamide gel electrophoresis as described above.

\section{Measurement of isoelecric point}

Isoelectric focusing was performed in a IEF-PAGE pH 3-10 Gel (4\% gel, TEFCO). The isoelectric focusing calibration kit $(\mathrm{pH} \mathrm{3-10)}$ was purchased from Amersham Pharmacia Biotech. Protein was stained with $0.25 \%$ Coomassie brilliant blue R-250.

\section{Paper chromatography}

Reaction products of xylanases as described above were assayed by paper chromatography. Each sample was spotted on a filter paper (No. 50, Toyoroshi). The paper developed by the multiple ascending method using the following solvent system: $n$-butanol-pyridinewater $(6: 4: 3, \mathrm{v} / \mathrm{v} / \mathrm{v})$. Saccharides were detected by an aniline hydrogen phthalic salt solution $^{15)}$. 


\section{$\mathrm{N}$-terminal amino acid sequences}

The N-terminal amino acid sequences were identified using a protein sequencer PPSQ-10 (Shimadzu). About $100 \mathrm{pmol}$ of pure proteins were used in each run.

\section{Results}

\section{Purification of xylan degrading enzymes}

Xylan degrading enzymes (xylanase I, xylanase II and $\beta$-xylosidase) were purified from the culture broth of $P$. expansum 0-385-10 grown in a salt medium containing $2.0 \%(\mathrm{w} / \mathrm{v})$ washed wheat bran $^{9)}$ as a xylan source. The purification procedures are described in Materials and Methods. These enzymes were easily

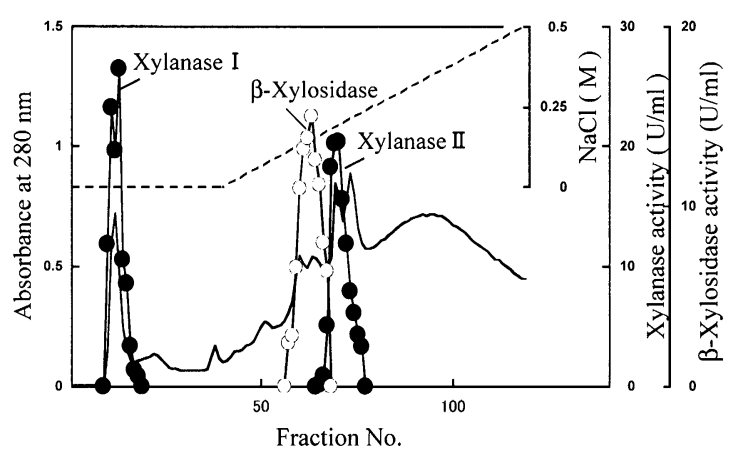

Fig. 1. Ion exchange chromatography of xylanases and $\beta$-xylosidase from $P$. expansum O-385-10 on DEAE cellulose DE-52. The column was eluted with a linear gradient of $0-0.5 \mathrm{M}$ sodium chloride in phosphate buffer ( $\mathrm{pH} 7.2$ ) at a flow rate of $10.0 \mathrm{ml} / \mathrm{h}$. Each fraction was collected in $10 \mathrm{ml} .(-)$, absorbance at $280 \mathrm{~nm}$; (๑), xylanase activity; (O), $\beta$-xylosidase activity; $(\cdots)$, concentration of $\mathrm{NaCl}$. separated from each other by the DEAECellulose column chromatography (Fig. 1). A typical purification of these three enzymes is summarized in Table 1 . The purified enzyme preparations of xylanase I, xylanase II and $\beta$ xylosidase were obtained in a yield of $4.96,4.34$ and $11.1 \%$, respectively, and had the specific activity of $846,1,460$ and $3.52 \mathrm{U} / \mathrm{mg}$ protein, respectively. The final purification factors were 46.7, 80.7 and 704-fold, respectively.

The purified enzymes were homogeneous as judged by the criterion of non-denaturing polyacrylamide gel electrophoresis and isoelectrophoresis. Moreover, no evidence of contamination was found on SDS-polyacrylamide gel electrophoresis [Fig. 2(A) and Fig. 2(B)].

\section{Molecular weight of the enzymes}

The molecular weights of xylanase I, xylanase II and $\beta$-xylosidase were estimated with HPLC on a TSK G-3000 SW (Tosoh) column and SDS-polyacrylamide gel electrophoresis method. The molecular weights of xylanase I, xylanase II and $\beta$-xylosidase were calculated to be about 21.0, 40.0 and $91.0 \mathrm{kDa}$, respectively [Fig. 2(A) and Fig. 2(B)].

\section{Isoelectric point of the enzymes}

The $\mathrm{p} I \mathrm{~s}$ of xylanase I, xylanase II and $\beta$ xylosidase were $9.20,4.30$ and 4.20 , respectively (Fig. 3).

\section{Characteristics of xylanase I and II}

\section{Effects of $\mathrm{pH}$ on the enzymes}

The optimum pHs of xylanase I and II were

Table 1. Summary of purification of xylanases and $\beta$-xylosidase produced by $P$. expansum 0-385-10

\begin{tabular}{|c|c|c|c|c|c|}
\hline Purification procedure & $\begin{array}{l}\text { Total protein } \\
(\mathrm{mg})\end{array}$ & $\begin{array}{c}\text { Total enzyme } \\
\text { activity } \\
\text { (U) }\end{array}$ & $\begin{array}{l}\text { Specific activity } \\
(\mathrm{U} / \mathrm{mg})\end{array}$ & $\begin{array}{l}\text { Yield } \\
(\%)\end{array}$ & $\begin{array}{l}\text { Purification } \\
\quad \text { (fold) }\end{array}$ \\
\hline \multicolumn{6}{|l|}{ Xylanases } \\
\hline Crude filtrate & 1,430 & 25,800 & 18.1 & 100 & 1 \\
\hline$\left(\mathrm{NH}_{4}\right)_{2} \mathrm{SO}_{4}$ (70\% sat.) & 412 & 22,900 & 55.6 & 88.8 & 3.07 \\
\hline \multicolumn{6}{|l|}{ Xylanases I } \\
\hline DEAE-cellulose DE-52 & 23.4 & 6,190 & 265 & 24.0 & 14.6 \\
\hline CM-cellulose & 3.85 & 1,820 & 473 & 7.05 & 26.1 \\
\hline Sephadex G-100 & 1.51 & 1,280 & 846 & 4.96 & 46.7 \\
\hline \multicolumn{6}{|l|}{ Xylanases II } \\
\hline DEAE-cellulose DE-52 & 25.8 & 5,110 & 198 & 19.8 & 10.9 \\
\hline Butyl-Toyopearl & 1.92 & 2,130 & 611 & 8.26 & 33.8 \\
\hline Sephadex G-150 & 0.32 & 1,120 & 1,460 & 4.34 & 80.7 \\
\hline \multicolumn{6}{|l|}{$\beta$-Xylanases } \\
\hline Crude filtrate & 1,430 & 7.65 & 0.005 & 100 & 1 \\
\hline$\left(\mathrm{NH}_{4}\right)_{2} \mathrm{SO}_{4}$ (70\% sat.) & 413 & 13.0 & 0.03 & 170 & 6 \\
\hline DEAE-cellulose DE-52 & 17.9 & 5.60 & 0.31 & 73.2 & 62 \\
\hline Butyl-Toyopearl & 2.64 & 1.68 & 0.64 & 22.0 & 128 \\
\hline Sephadex G-150 & 0.24 & 0.85 & 3.52 & 11.1 & 704 \\
\hline
\end{tabular}


A

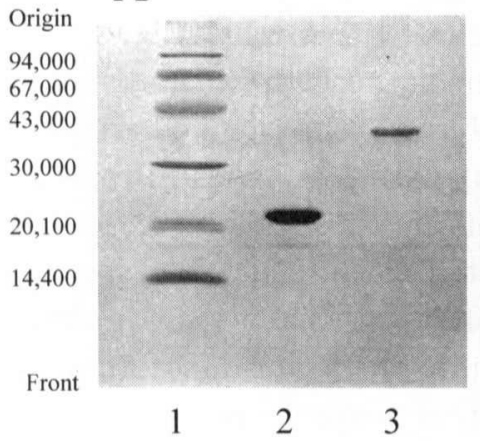

B

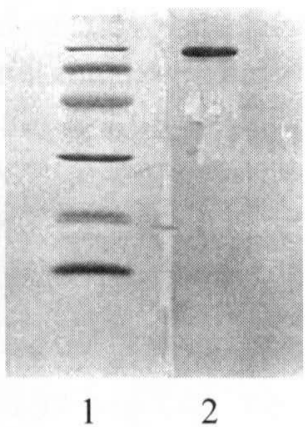

Fig. 2. SDS-polyacrylamide gel electrophoresis of $\mathrm{xy}$ lanases (xylanse I, xylanase II) and $\beta$-xylosidase from $P$. expansum 0-385-10 Electrophoresis of denaturedxylanase I, xylanase II and $\beta$-xylosidase was done on $13.5 \%$ SDS polyacrylamide gel. A: Lane $1, M_{\mathrm{r}}$ standards: phosphorylase $b(94,000)$, bovine serum albumin $(67,000)$, ovalbumin $(43,000)$, carbonic anhydrase $(30,000)$, soybean trypsin inhibitor $(20,100), \alpha$-lactalbumin $(14,000)$. Lane 2, xylanase I. Lane 3, xylanase II. B: Lane 1, $M_{r}$ standards: the same with A. Lane $2, \beta$-xylosidase.

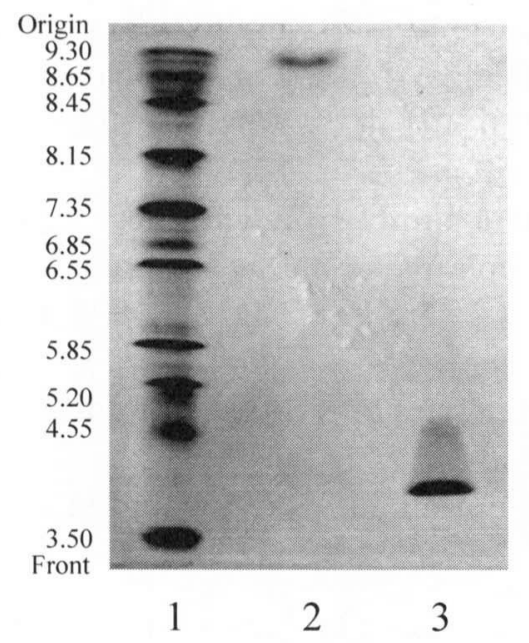

Fig. 3. Isoelectric focusing of xylanase I and xylanase II from $P$. expansum O-385-10 Electrophoresis was carried out with IEF-PAGE gel mini (pH 3-10, 4\% gel). Lane 1, $\mathrm{p} I$ standards: amyroglucosidase (3.50), soybean trypsin inhibitor (4.55), $\beta$-lactoglobulin A (5.2), bovine carbonic anhydrase B (5.85), human carbonic anhydrase B (6.55), horse myoglobin (6.85), horse myoglobin (7.35), lentil lectin (8.15), lentil lectin (8.45), lentil lectin (8.65), trypsinogen (9.3). Lane 2, xylanase I. Lane 3, xylanase II.

about equal values of around 4.3. Xylanase I was stable in the wide $\mathrm{pH}$ range of 3 to 9 , while the stability of xylanase II was in the narrower $\mathrm{pH}$ range of 5 to 8 .

\section{Effects of temperature on the enzymes}

The optimum temperatures of xylanase I and II were about equal values of around $40^{\circ} \mathrm{C}$

Table 2. Effect of metal ions on activity of $\mathrm{xy}$ lanases of P. expansum 0-385-10

\begin{tabular}{ccc}
\hline \multirow{2}{*}{$\begin{array}{c}\text { Ion added } \\
(1 \mathrm{mM})\end{array}$} & \multicolumn{2}{c}{ Relative enzyme activity } \\
& \multicolumn{2}{c}{$(\%)$} \\
\cline { 2 - 3 } None & 100 & Xylanase II \\
$\mathrm{K}^{+}$ & 207 & 100 \\
$\mathrm{Ca}^{2+}$ & 269 & 81 \\
$\mathrm{Fe}^{2+}$ & 229 & 75 \\
$\mathrm{Zn}^{2+}$ & 253 & 41 \\
$\mathrm{Ni}^{2+}$ & 228 & 61 \\
$\mathrm{Cu}^{2+}$ & 116 & 75 \\
$\mathrm{Mn}^{2+}$ & 21 & 9 \\
$\mathrm{Hg}^{2+}$ & 6 & 32 \\
$\mathrm{Ba}^{2+}$ & 216 & 1 \\
$\mathrm{Mg}^{2+}$ & 207 & 96 \\
\hline
\end{tabular}

under the standard assay conditions. Both enzymes were rapidly inactivated above $30^{\circ} \mathrm{C}$.

Effects of metal ions on the enzyme activities

The effects of metal ions on purified xylanase I and II were examined (Table 2). The activity of xylanase II was inhibited by $\mathrm{Ca}^{2+}$, $\mathrm{Fe}^{2+}, \mathrm{Ni}^{2+}$ and $\mathrm{Zn}^{2+}$, while the activity of xylanase I was strongly activated by these ions. In addition, xylanase I was also strongly activated by $\mathrm{K}^{+}$ion. Both enzymes were inhibited by $\mathrm{Mn}^{2+}, \mathrm{Hg}^{2+}$.

Reaction specificities of the enzymes and reaction products

The reactions of purified xylanases with oat xylan and xylotriose were examined (Fig. 4). The reaction profile of xylanase I was clearly different from that of xylanase II. Xylanase I mainly produced oligomers of xylose such as xylobiose, xylotriose, and probably xylotetraose, from xylan. In contrast, xylanase II mainly produced xylose and xylobiose from the early stage of the reaction, and higher oligosaccharides were hardly detected in the incubation mixture through the reaction. When xylanase I was incubated with xylotriose, xylobiose was mainly produced, and small amounts of xylose and xylotetraose were detected in the incubation mixture. In the case of xylanase II, the enzyme almost completely decomposed xylotriose to xylose and xylobiose. Neither xylanase I nor xylanase II could hydrolyze xylobiose.

\section{$\mathrm{N}$-terminal amino acid sequences}

The N-terminal amino acid sequences of the purified xylanase I and II were compared to those of enzymes from some fungi and bacteria whose complete sequences were already 


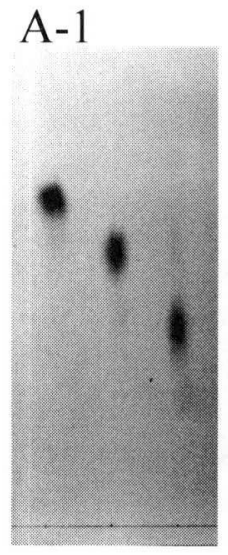

123

B-1

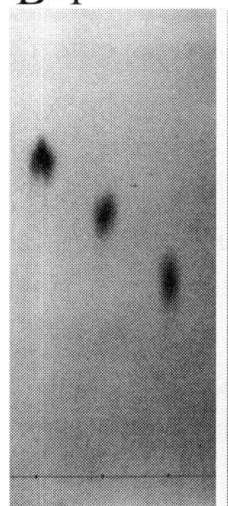

123
A-2

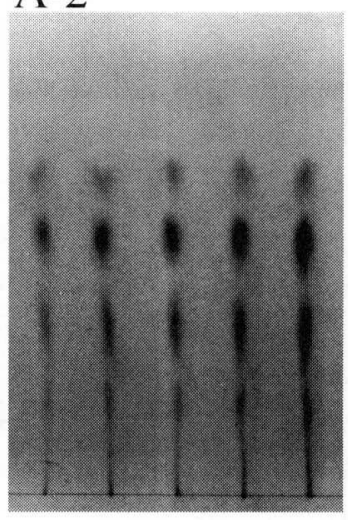

$1 \mathrm{~h} \quad 2 \mathrm{~h} \quad 4 \mathrm{~h} \quad 6 \mathrm{~h} \quad 12 \mathrm{~h}$
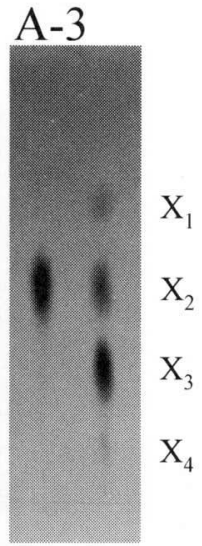

B-2

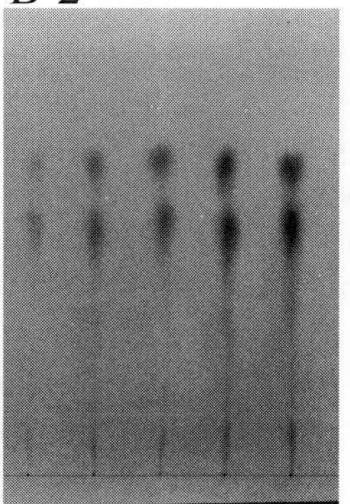

1h $2 \mathrm{~h} \quad 4 \mathrm{~h} \quad 6 \mathrm{~h} \quad 12 \mathrm{~h}$
B-3

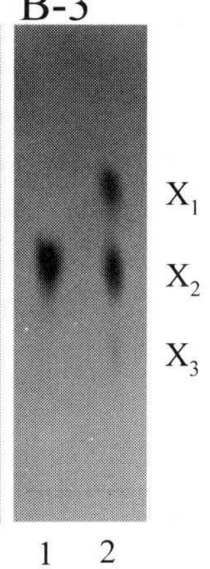

Fig. 4. Paper chromatogram of hydrolyzates produced from xylan by xylanase I and II from P. expansum 0-385-10 A-1: standards. Lane 1, xylose; Lane 2, xylobiose; Lane 3, xylotriose. A-2: xylan hydrolysis by xylanase I after various incubation time (1-12 hr). A-3: Lane 1, xylobiose hydrolysis by xylanase I; Lane 2, xylotriose hydrolysis by xylanase I. B-1: standards: the same with A-1. B-2: xylan hydrolysis by xylanase II after various incubation time. B-3: Lane 1, xylobiose hydrolysis by xylanase II; Lane 2, xylotriose hydrolysis by xylanase II.

known. The enzymes of these organisms belong to family 11 xylanase $^{16,17)}$. Figure 5 shows that xylanase I of $P$. expansum can probably be assigned to family 11 enzyme. On the other hand, it was not possible to read the Nterminal amino acid of xylanase II, indicating that the N-terminus of the enzyme was blocked. Action of xylanase I, xylanase II and $\beta$ xylosidase on apple fruit

The effects of purified enzymes on apple fruit tissue were examined by measuring the reducing sugar liberated (Fig. 6). When xylanase I and II were incubated with a piece of apple fruit, respectively, almost no increase of reducing sugar could be observed in the incuba-

Xylanase I (this study)
P.s XynA
A.nd XlnB
S.livi. XInC
S.sp.S38 Xyll

1 AITSNEQGTNNGYFYSFWTNGGG

33 TITSSQTGTNNGYYYSFWTNGGG

33 RSTPSSTGTSGGYYYSFWTDGGG

3 TITTNQTGY.DGMYYSFWTDGGG

3 VITTNETGTNNGYYYSFWTDGGG

Fig. 5. N-terminal amino acid sequences of xylanase I from P. expansum O-385-10 and comparison with family 11 xylanase from fungi and bacteria. P.s XynA, xylanase A from Penicillium sp. 40; A.nd XlnB, xylanase B from Aspergillus nidulans; S.livi. XlnC, xylanase C from Streptomyces lividans; S.sp. S38 Xy11, xylanase 1 from Streptomyces sp. S38.

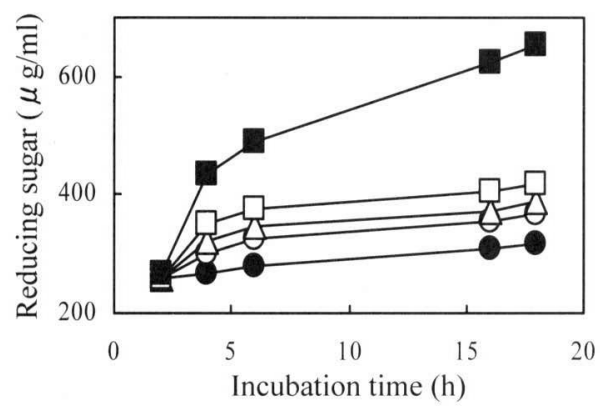

Fig. 6. Liberation of reducing sugar from apple fruit. Discs ( $5 \mathrm{~mm}$ in diameter, $2 \mathrm{~mm}$ in thickness) obtained from apple fruit were incubated with each enzyme (about $5 \mathrm{U}$ ) at $30^{\circ} \mathrm{C}$. apple; $(\bigcirc)$, apple + xylanase I; $(\triangle)$, apple + xylanase II; $(\square)$, apple $+\beta$-xylosidase; apple $+\mathrm{xylanase} \mathrm{I}+\mathrm{xylanase} \mathrm{II}+\beta$-xylosidase.

tion mixture. A similar result was obtained when xylanase I and II were simultaneously incubated with the fruit. A clear increase of reducing sugar liberated from the fruit was observed when $\beta$-xylosidase was added to the incubation mixture of xylanases.

\section{Discussion}

In cultures of several Penicillium species, xylanolytic activities have been found ${ }^{18-20}$. There have heen a few reports on the enzyme purified as a homogeneous protein from Penicilblium capsulatum and Penicillium purpurogenum $^{18,20)}$. However, little is known about relationship between the physioloy of xylanolytic enzyme from phytopathogenic organisms and the components of host plant tissue. Penicillium expansum 0-385-10 extracellularly produced a large amount of the xylan-degrading enzyme that played a role in the decomposition of apple cell wall ${ }^{2}$. In this work, the xylandegrading enzyme was purified, and xylanase I, xylanase II and $\beta$-xylosidase were obtained as electrophoretically homogeneous proteins, 
respectively.

The profile of the xylan hydrolysis by $x y$ lanase I and II showed that these were the end type enzyme. However, the profiles of the hydrolysis reaction are remarkably different between both enzymes. In the reaction mixture with xylanase I, various xylooligosaccharides and a small amount of xylose were detected through the reaction. The reaction of xylanase I was similar to that of usual endo-xylanase ${ }^{21)}$. On the other hand, xylanase II formed mainly xylose and xylobiose from the initial time of the incubation, and production of oligosaccharides was hardly observed through the reaction. Little is known about how endoxylanase splits to the monomer of xylose from the early stage of the reaction with xylan. In the study of Tseng et $a l^{22)}$, co-incubation of the two endoxylanases from Bacillus firmus with xylan resulted in the release of xylose and the production of xylose was also shown to be increased with time. However, only a trace amount of xylose was detected at the time of adding solely xylanase. This suggested that different patterns of products released from the substrate correspond to different affinities of xylanase I and II for the substrate. There were also remarkable differences in the effects of metal ions on the enzyme activity between xylanase I and xylanase II. The activity of xylanase I was strongly enhanced by $\mathrm{K}^{+}, \mathrm{Ca}^{2+}, \mathrm{Fe}^{2+}, \mathrm{Ni}^{2+}$ and $\mathrm{Zn}^{2+}$ ions, while the activity of xylanase II was inhibited by all of these ions except $\mathrm{K}^{+}$. There has been no report about the effects of $\mathrm{K}^{+}$ion on xylanase activity. It is interesting that $x y$ lanase I was strongly activated by $\mathrm{K}^{+}$ion which is plentiful in apple fruit. $\mathrm{K}^{+}$ions of plant cells are usually localized in the protoplasm. The intracellular $\mathrm{K}^{+}$ions leak out when pathogenic organisms degrade the cells of host plant ${ }^{6,23)}$. Therefore, the effect of $\mathrm{K}^{+}$ions leaking out from host plant cells due to degrading enzymes of a pathogen is closely related to pathogenic activity.

It has been proposed that xylanase was classified into two groups of acidic highmolecular-mass enzyme (family 10) and basic low-molecular-mass enzyme (family 11) 24-26). $^{2}$. Xylanase I $\left(\mathrm{p} I, 9.20 ; M_{\mathrm{r}}, 21.0 \mathrm{kDa}\right)$ of strain O385-10 belongs to the basic low-molecular enzyme and xylanase II $\left(\mathrm{p} I, 4.30 ; M_{\mathrm{r}}, 40.0 \mathrm{kDa}\right)$ belongs to the acidic high-molecular enzyme. The N-terminal amino acid arrangement of $\mathrm{xy}$ lanase I shows a strong homology to that of several family 11 xylanases. As for xylanase II, it was not possible to read the $\mathrm{N}$-terminal amino acids. From these facts, xylanase I seems to be a family 11 enzyme. At present time, the grouping of xylanase II is undecided.

There have been a few reports on the relationship between the components of apple fruit tissue and a purified carbohydrate degrading enzyme produced by fungi. Sasaki et al. ${ }^{4-7)}$, reported that $\beta$-glucosidase played an important role on the degradation of the pulp of apple by a phytopathogenic fungus, Botrytis cinerea. In the culture of $P$. expansum O-385-10, $\beta$ glucosidase has not been found ${ }^{2}$. Xylanase I, II and $\beta$-xylosidase purified independently from strain 0-385-10 did not affect apple fruit. When these enzymes were simultaneously incubated with apple fruit, a large amount of reducing sugar was liberated into the incubation mixture. This suggested that the cooperative and synergistic attack of xylanases and $\beta$ xylosidase against the apple tissue liberates a large amount of reducing sugar. From these facts, it seems that $P$. expansum O-385-10 spreads using three xylan degrading enzymes in apple fruit.

The authors are very grateful to Nitto Flour Milling Co., Ltd. for providing washed wheat bran.

\section{References}

1) Pierson, C.F., Ceponis, M. J. and McColloch, L.P.: Market diseases of apples, pears, and quinces. U.S Dept. Agric., Agric. Handbook 376. U.S. Govt. Printing Office, Washington, D.C. (1971).

2) Kimura, S., Ohno, N., Fukuda, H., Takahashi, H., Shinoyama, $\mathrm{H}$. and Fujii, T.: Growth characteristics and productivity of fruit-degrading enzymes in an apple blue mold, Penicillium expansum. Jpn. J. Food Microbiol. (in Japanese), 16, 171-179 (1999).

3) Kimura, S., Amachi, S., Ohon, N., Takahashi, H., Shinoyama, H. and Fujii, T., Relationship between conidial enzymes and germination of the apple blue mold, Penicillium expansum. Biosci. Biotechnol. Biochem., 66(5), 1126- 1129 (2002).

4) Sasaki, I. and Nagayama, H.: $\beta$-Glucosidase from Botrytis cinerea: Its relation to the pathogenicity of this fungus. Biosci. Biotechnol. Biochem., 58, 616620 (1994).

5) Sasaki, I. and Nagayama H.: Purification and charac- 
terization of $\beta$-glucosidase from Botrytis cinerea. Biosci. Biotechnol. Biochem., 59, 100-101 (1995).

6) Sasaki, I. and Nagayama, H.: $\beta$-glucosidase of Botrytis cinerea: Its involvement in the pathogenicity of this fungus. Biosci. Biotechnol. Biochem., 60, 54-56 (1996).

7) Sasaki, I. and Nagayama, H.: Induction of $\beta$ glucosidase in Botrytis cinerea by cell wall fractions of the host plant. Biosci. Biotechnol. Biochem., 61, 10731076 (1997).

8) Conway, W. S., Gross, K. C., Boyer, C. D. and Sams, C. E.: Inhibition of Penicillium expansum polygalacturonase activity by increased apple cell wall calcium. Phytopathology, 78, 1052-1055 (1988).

9) Sasaki, Y., Tamai, Y., Hayashi, Y., Kubota, S., Fujio, T., Ogasawara, T., Egashira, Y., Sanada, H. and Ayano, Y.: Effect of wheat bran on cholesterol metabolism in rats. J. Jpn. Soc. Nutr. Food Sci. (in Japanese), 44, 461470 (1991).

10) Nelson, N.: Nelson's method for quantitative determination of reducing power of carbohydrates. J. Biol. Chem., 153, 375-380 (1944).

11) Lowry, O. H., Rosebrough, N. J., Farr. A. L., and Randall, R. J.: Protein measurement with the Folin phenol reagent. J. Biol. Chem., 193, 265 (1951).

12) Davis, B. J.: Disc electrophoresis-method and application to human serum proteins. Ann. N.Y. Acad. Sci., 121, 404-427 (1964).

13) Laemmi, U. K.: Cleavage of structural proteins during the assembly the head of bacteriophage T4. Nature, 227, 680-685 (1970).

14) Laemmi, U. K. and Farve, M.: Maturation of the head of bacteriophage T4. J. Mol. Biol., 80, 575-599 (1973).

15) Partridge, S. M., Nature, 164, 443 (1949).

16) Georis, J., Giannotta, F., Buyl, E. D., Granier, B. and Frère, J. M.: Purification and properties of tree endo$\beta-1,4-x y l a n a s e s$ produced by Streptomyces sp. strain S38 which differ in their ability to enhance the bleaching of kraft pulps. Enzyme Microb. Technol., 26, 178-186 (2000).

17) Ohta, K., Moriyama, S., Tanaka, H., Shige, T. and
Akimoto, H.: Purification and characterization of an acidophilic xylanase from Aureobasidium pullulans var. melanigenum and sequence analysis of the encoding gene. J. Biosci. Bioeng., 92, 262-270 (2001).

18) Belancic, A., Scarpa, J., Peirano, A., Díaz, R., Steiner, J. and Eyzaguirre, J.: Penicillium purpurogenum produces several xylanase: Purification and properties of two of the enzymes. J. Biotechnol., 41, 71-79 (1995).

19) Abdel-Sater, M. A. and El-Said, A. H. M.: Xylandecomposing fungi and xylanolytic activity in agricultural and industrial wastes. Int. Biodeterior Biodegrad., 47, 15-21 (2001).

20) Filho, E. X. F., Tuohy, M. G., Puls, J. and Coughlan, M. P.: The xylan-degrading enzyme systems of Pencillium capsulatum and Talaromyces emersonii. Biochem. Soc. Trans., 19, 25S (1991).

21) Biely, P., Vršanská, M., Tenkanen, M. and Kluepfel, D.: Endo- $\beta$-1,4-xylanase families: differences in catalytic properties. J. Biotechnol., 57, 151-166 (1997).

22) Tseng, M. J., Yap, M. N., Ratanakhanokchai, K., Kyu, K. L. and Chen, S. T.: Purification and characterization of two cellulose free xylanases from an alkaliphilic Bacillus firmus. Enzyme and Microb. Technol., 30, 590-595 (2002).

23) Lenna, P. Di. and Fielding, A. H.: Multiple forms of polygalacturonase in apple and carrot tissue infected by isolates of Botrytis cinerea. J. Gen. Microbiol., 129, 3015-3018 (1983).

24) Wong, K. K. Y., Tan, L. U. L. and Saddler, J. N.: Multiplicity of $\beta$-1,4-xylanase in microorganisms: functions and applications. Microbiol. Rev., 52, 305-317 (1988).

25) Gilkes, N. R., Henrissat, B., Kilburn, D. G., Miller, R. C. Jr. and Warren, A. J.: Domains in microbial $\beta$-1,4glycanases: sequence conservation, function and enzyme families. Microbiol. Rev., 55, 303-315 (1991).

26) Henrissat, B. and Bairoch, A.: New families in the classification of glycosyl hydrolases based on amino acid sequence similarities. Biochem. J., 293, 781-788 (1993).

\title{
リンゴ果実の腐敗に関与する Penicillium expansum 0-385-10 の 生産するキシラン分解酵素の精製と諸性質
}

\author{
大野信 子*1 ・ 福田晴 美*1 ・ 木村聡一郎*2 ・金 賢 雄*2 \\ 高橋治男*3 $・$ 天知誠吾*2 ・篠山浩文*2 ・藤井貴明*2 \\ ( ${ }^{* 1}$ 和洋女子大学家政学部健康栄養学科, $* 2$ 千葉大学大学院自然科学研究科, ${ }^{* 3}$ 千葉県衛生研究所)
}

リンゴ果実の腐敗に関与する Penicillium expansumt O-385-10 の液体培養上清液から，キシラン分解酵素（キシラ ナーゼ I，キシラナーゼ II， $\beta$-キシロシダーゼ）を電気泳動ならびに等電点電気泳動的に単一なまでに精製した．キシ ラナーゼ I，キシラナーゼII および $\beta$-キシロシダーゼの分子量はそれぞれ，21.0, 40.0, $91.0 \mathrm{kDa}$, 等電点はそれぞれ, 9.20, 4.30, 4.20 と算出した. キシラナーゼI は，キシランから少量のキシロースおよび多量の数種のキシロオリゴ糖 を生成した。これに対して, キシラナーゼII は反応初期から主にキシロースやキシロビオスを生成し, キシロトリ 
268 日食微誌 Vol. 21 No. 42004

オース以上のオリゴ糖はほとんど生成しないことがわかった． $\mathrm{K}^{+}$イオンによりキシラナーゼ $\mathrm{I}$ の活性は約 2 倍に賦 活化された.一方のキシラナーゼ II は約 $80 \%$ まで阻害された。 これらの精製酵素をリンゴ果害に作用させた場合, キ シラナーゼIやII だけではリンゴからの還元糖生成はほとんど見られなかったのに対し， $\beta$-キシロシダーゼを同時に 作用させることにより果実からの遊離還元糖が著しく増加してきた。 